\title{
Giresun İli Uzatma Ağı Balıkçılığının Sosyo-Demografik Yapısı ve Kalkan Balığı (Scophthalmus maximus Linnaeus, 1758) Balıkçılığı Üzerine Bir Tespit
}

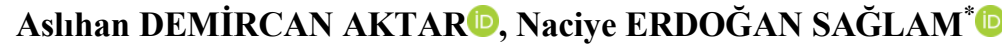

Ordu Üniversitesi, Fatsa Deniz Bilimleri Fakültesi, Balıkçılık Teknolojisi Mühendisliği Bölümü, Fatsa-Ordu, Türkiye

*Sorumlu yazar: nes-34@hotmail.com

Geliş 26 Aralık 2019; Kabul 20 Nisan 2020; Basım 01 Haziran 2020.

\begin{abstract}
Alıntılama: Demircan Aktar, A., \&Erdoğan Sağlam, N. (2020). Giresun ili uzatma ağı balıkçılığının sosyo-demografik yapısı ve kalkan balığı (Scophthalmus maximus Linnaeus, 1758) balıkçılığı üzerine bir tespit. Acta Aquatica Turcica, 16(2), 275-282. https://doi.org/10.22392/actaquatr.665381
\end{abstract}

\section{Özet}

Bu çalışmada, Giresun İli sınırları içerisinde uzatma ağı kullanan balıkçıların sosyo-demografik ve ekonomik durumları ile kalkan balığı avcılığında kullanılan teknelerin ve ağların teknik özellikleri ile yakalanan kalkan balıklarının boy kompozisyonları araştırılmışır. Bu amaçla 53 adet balıkçı ile yüz yüze görüşmeler yapılmış, kalkan avcılığı yapan balıkçıların teknelerinin ve ağlarının özellikleri incelenmiştir. Çalışmada balıkçıların \%25 ile çoğunluğunun 40-49 yaş aralığında olduğu görülmektedir. Giresun ilindeki balıkçıların öğrenim durumlarına bakıldığında \%57'sinin ilkokul, \%13'ünün ortaokul, \%24'ünün lise, \%2'sinin meslek yüksekokulu ve \%4'ünün fakülte mezunu olduğu tespit edilmiștir. Balıkçıların \%94'ünün kendisine veya ailesine ait teknesi olduğu belirlenmiştir. \%21'inin eşlerinin çalıştığı, \%79'unun çalışmadığı ve balıkçıların teknelerini bakıma aldıklarında eşlerinin ağ dokuma işlerinde kendilerine yardımcı olduğu belirtilmiştir. Çalışma süresince incelenen 203 adet kalkan balığının, minimum, maksimum ve ortalama boyları sırasıyla,

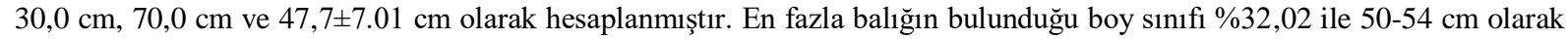
belirlenmiştir. Karadeniz'de Kalkan balığı avcılığının her geçen yıl bir önceki yıla göre önemini daha da kaybetmekte olduğu anlaşılmaktadır.

Anahtar kelimeler: Giresun İli, Uzatma ağı balıkçıları, Sosyo-demografi, Kalkan balığı

Socio-Demographic Structure of Gillnet Fisheries and Determination on Turbot (Scophthalmus maximus Linnaeus, 1758) Fisheries in Giresun

\section{Abstract}

This study aimed to determine the socio-demographic and economic status of turbot fishermen in Giresun province. Faceto-face interviews were conducted with 53 fishermen and the characteristics of boats and nets were examined. In the study, it is seen that the majority of fishermen $(25 \%)$ are in the 40-49 age range. When the education level of fishermen in Giresun province is examined, it is found that $57 \%$ are primary, $13 \%$ are secondary, $24 \%$ are a high school, $2 \%$ are vocational high school and $4 \%$ are faculty graduates. It is determined that $94 \%$ of the fishermen have a boat that belongs to him or his family. It was stated that $21 \%$ of spouses of fishermen work, $79 \%$ do not work and when fishermen took the boat into maintenance, their spouses helped in gillnet repairing. The minimum, maximum and average lengths of 203 turbots examined during the study were $30.0 \mathrm{~cm}, 70.0 \mathrm{~cm}$, and $47.7 \pm 7.01 \mathrm{~cm}$, respectively. The length class with the most fish was captured is $50-54 \mathrm{~cm}$ with $32.02 \%$. Turbot fishing in the Black Sea decreases every year compared to the previous years and as a result, the number of turbot fishermen is also decreasing.

Keywords: Giresun, Gillnet, Socio-demographic, Turbot Fisheries

\section{GíRIŞ}

Doğu Karadeniz Bölgesi, ülkemizin balıkçılık bakımından en önemli merkezlerinden biridir. Giresun'un lokasyonu nedeniyle halkının büyük bölümü balıkçılıkla geçimini sağlamakta ve daha çokta yapılan balıkçılık uzatma ağı balıkçılı̆̆ şeklindedir. Toplamda balıkçıların 2385 adet uzatma ağ ile balıkçılık yaptıkları bilinmektedir (Anonim, 2018a).

Karadeniz ve Marmara Denizi sularında Scophthalmidae ailesine ait 3 tür Scophthalmus maximus (Linnaeus, 1758), S. maeoticus (Pallas, 1814), S. rhombus (Linnaeus, 1758) bulunmaktadır (Nelson, 1994; Turan, 2007). Bu 3 türün birbirlerinden morfolojik olarak ayırt edilmesi çok zor olduğundan, 
Karadeniz için yapılan çalışmalarda genel olarak Scophthalmus maximus, türü referans olarak gösterilmiştir (Muus ve Dahlström, 1978; Suziki vd., 2004; Turan vd., 2019 ).

Ekonomik olarak önemli bir balık türü olan Kalkan balığı avcılığına ülkemizde,19. Yüzyılda başlanmıştır. Kalkan balığı avcılık dağılım alanı Karadeniz'de Kerç Boğazı ve Tuna Deltası açılarına kadar uzanırken, Karadeniz ülkeleri olan Rusya, Ukrayna, Romanya ve Bulgaristan ile 1982 ve 1986 yılları arasında yapılan çeşitli anlaşmalar doğrultusunda avcılık dağılım alanımız kendi kıta sahanlığımız içerisine indirgenmiştir. (Acara, 1985; Yıldız ve Karakulak, 2010; Ergüven, 2014; Özdemir vd., 2017).

Kalkan balığı avcılığında kullanılan dip uzatma ağları dönek (bırakma) şeklinde kullanılmakta ve ağlar denize bırakıldıktan 1 hafta ile 10 gün sonrasında toplanmaktadır. Kalkan balığı avcılığı martnisan aylarında yapılmaktadır. 2016-2020 dönemi 4/1 no ’lu tebliğe göre 15 Nisan-15 Haziran tarihleri arasında her türlü istihsal vasitası ile bölgede kalkan avcılı̆̆ yapılması ve kalkan ağlarının denizde bırakılması yasaktır. Kalkan avcılığında kullanılacak ağların göz açıklığı 400 mm’den küçük olamaz. Avlanan kalkan balığının boyu $45 \mathrm{~cm}$ 'den büyük olmalıdır (Anonim b, 2018).

Geçmiş yıllara göre kalkan balığı avcılığında azalmalar dikkat çekmektedir. 2018 yılı TÜİK istatistiklerine göre kalkan balığı av miktarı 139,2 tondur. Kalkan balığı, av miktarının az olmasına karşın ekonomik değeri çok yüksek bir balıktır (Anonim a, 2018). Bu çalışmada, Karadeniz küçük ölçekli balıkçığında önemli bir yere sahip olan Giresun ilinde, kalkan balıkçılığında kullanılan uzatma ağı özellikleri, avlanan kalkan balıklarının yasal boy sınırlarına göre boy oranları ve balıkçıların sosyo-demografik yapılarının incelenmesi ve balıkçılığın bölge insanının yaşamında sosyal ve ekonomik anlamdaki yerinin belirlenmesi amaçlanmıştır.

\section{MATERYAL ve YÖNTEM}

Araştırma 2017-2018 av sezonunda Giresun İli sahil şeridinde yer alan Piraziz, Bulancak, Merkez, Keşap, Espiye, Tirebolu, Görele ve Eynesil ilçelerinde gerçekleştirilmiştir (Şekil 1). Sezonuna göre kalkan balığı avcılığı yapan balıkçıların sosyo-demografik ve ekonomik durumunu ortaya koymak üzere 53 adet balıkçı ile yapılan yüz yüze görüşmeler çoktan seçmeli sorularla yapılmıştır. Kalkan avcılığı yapan balıkçıların teknelerinin ve ağlarının özellikleri incelenmiştir. Balıkçılardan elde edilen 203 adet kalkan balığının boy kompozisyonu değerlendirilmiştir. Balıkçıların yaş ve eğitim durumları, çocuk sayıları, sosyal güvence durumları, kaç yıldır balıkçılık yaptığı, balıkçılığ1 seçme nedenleri, kooperatif üyelikleri vb gibi sorular irdelenmiştir.

Çalışma süresince elde edilen veriler, Excel programında düzenlenmiş, tablo ve grafikler halinde sunulmuştur.

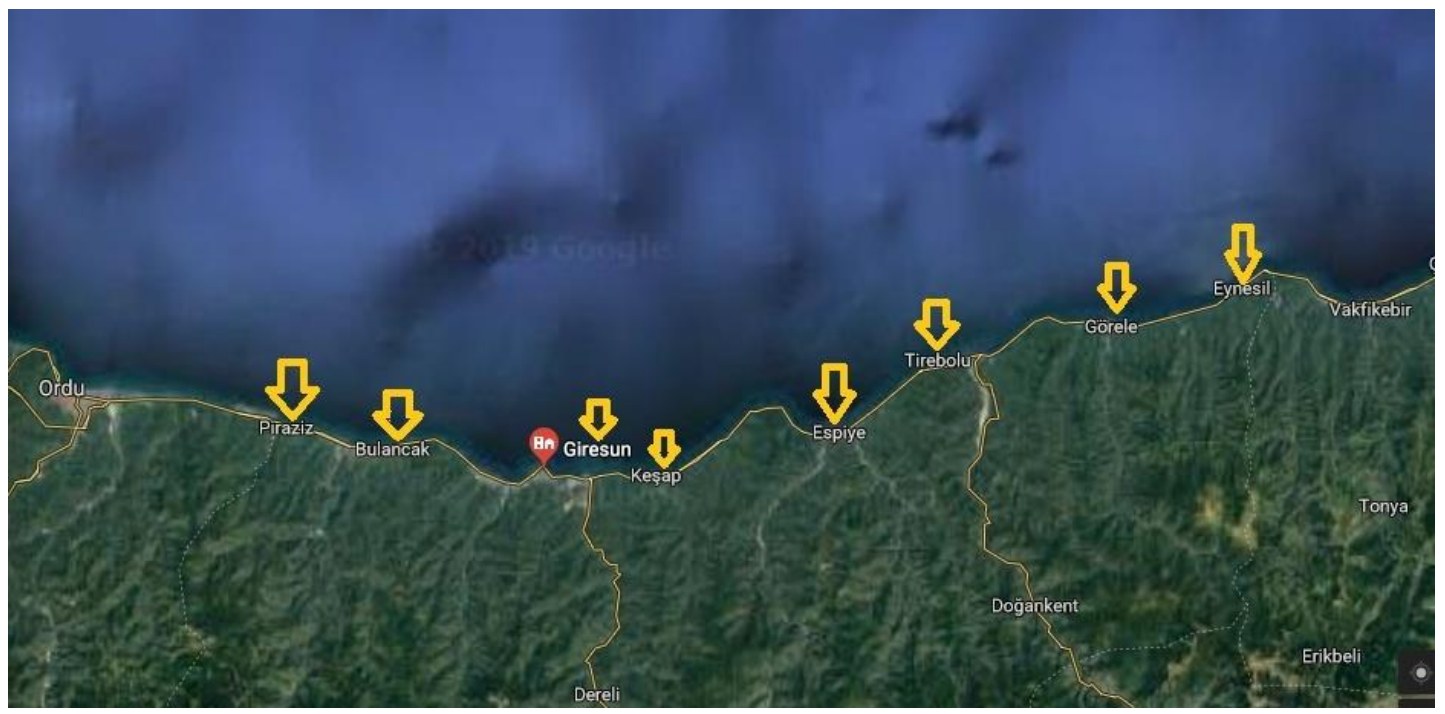

Şekil 1. Araştırma Sahası 


\section{BULGULAR}

Çalışma bulguları, bölge içerisinde kalkan balıkçılığı ile uğraşan balıkçıların sosyo-demografik durumu, balıkçıların ekonomik durumu, kalkan balı̆̆ 1 avcılığında kullanılan teknelerin ve ağların özellikleri ve teknelerden elde edilen kalkan balıklarının boy kompozisyonu olmak üzere dört ana başlık altında değerlendirilmiştir.

\section{Balıkçıların Sosyo-Demografik Durumu}

Araştırmada kalkan avcılığı yapan balıkçılarda dahil kıyı balıkçılığı yapan toplam 53 adet balıkçıya ait sosyo-demografik özellikler Tablo 1'de verilmiştir. Yaşları 32 ile 74 arasında değişen balıkçıların \%42 oranı ile çoğunluğu 40-49 yaş grubundadır. Balıkçıların tamamı okur-yazar olup \%57'si ilkokul mezunudur. Tamamı erkek olan balıkçıların \%91'inin evli olduğu ve sahip olunan çocuk sayısının en fazla 4 olduğu belirlenmiştir. Evli olan balıkçıların \%79'unun eşinin çalışmadığı tespit edilmiştir. Balıkçıların mesleki deneyimi 4 ile 60 yıl arasında değişmekle birlikte $\% 98$ oranı ile çoğunluğunun 11 yıl ve üzeri deneyime sahip olduğu belirlenmiştir. Sahip olduğu teknede 1-42 yıl arasında çalıştığını belirten balıkçıların \%91'i teknede kaptan olarak görev yapmaktadır.

Balıkçıların \%51'i baba mesleği olması nedeniyle balıkçılık yaptığını, \%38'i ise işsizlik ve ekonomik sıkıntılar nedeniyle balıkçılık yapmak zorunda olduklarını ifade etmişlerdir. Ayrıca \%39'unun sosyal güvencesi olmakla birlikte, emekli olan \%23'ünün ek gelir amaçlı balıkçılık yaptığ1 belirlenmiştir. Balıkçıların \%60'1 yıl boyunca avcılık yaparken, \%11'i ara vererek teknelerinin bakım işleriyle ilgilendiklerini, \%27'si ise avcıllğa ara vererek perakende balık satışı yaptıklarını belirtmişlerdir(Tablo 1).

Tablo1. Balıç̧ıların Sosyo-Demografik Özellikleri

\begin{tabular}{|c|c|c|c|c|c|}
\hline $\begin{array}{l}\text { Özellikler } \\
\end{array}$ & 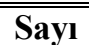 & $\%$ & \multicolumn{3}{|c|}{ Sosyal Güvenlik Durumu } \\
\hline \multicolumn{3}{|l|}{ Cinsiyeti } & Var & 21 & 39 \\
\hline Erkek & 53 & 100 & Yok & 20 & 38 \\
\hline Kız & - & - & Emekli & 12 & 23 \\
\hline \multicolumn{3}{|l|}{ Yaşı } & \multicolumn{3}{|c|}{ Sahip Olduğu Teknede Çalıșma Süresi (yıl) } \\
\hline $20-29$ & 3 & 4 & $\leq 5$ & 25 & 47 \\
\hline $30-39$ & 12 & 23 & $6-10$ & 10 & 19 \\
\hline $40-49$ & 22 & 42 & $\geq 11$ & 18 & 34 \\
\hline $50-59$ & 13 & 25 & \multicolumn{3}{|c|}{ Teknedeki Göreviniz Nedir? } \\
\hline$\geq 60$ & 3 & 6 & Kaptan & 48 & 91 \\
\hline \multicolumn{3}{|c|}{ Ĕgitim Düzeyi } & Tayfa & 5 & 9 \\
\hline İlkokul & 30 & 57 & \multicolumn{3}{|c|}{ Yıllık Çalıșma Süresi (ay) } \\
\hline Ortaokul & 7 & 13 & $4-6$ & 9 & 17 \\
\hline Lise & 13 & 24 & $7-9$ & 18 & 34 \\
\hline Üniversite & 3 & 6 & $10-12$ & 26 & 49 \\
\hline \multicolumn{3}{|c|}{ Medeni Durumu } & \multicolumn{3}{|c|}{ Balıkçılık Mesleğinden memnun musunuz? } \\
\hline Evli & 32 & 91 & Evet & 27 & 51 \\
\hline Bekar & 1 & 9 & Hayır & 26 & 49 \\
\hline \multicolumn{3}{|c|}{ Hane Halkı Sayısı (adet) } & \multicolumn{3}{|c|}{ Balıkçılığı Seçme Nedeni } \\
\hline$\leq 2$ & 4 & 8 & Baba mesleği & 27 & 51 \\
\hline $3-4$ & 21 & 40 & İșsizlik & 20 & 38 \\
\hline$\geq 5$ & 28 & 52 & Hobi & 6 & 11 \\
\hline \multicolumn{3}{|c|}{ Çocuk Sayısı (adet) } & \multicolumn{3}{|c|}{ Sigara Kullanıyor musunuz? } \\
\hline Yok & 6 & 11 & Evet & 31 & 58 \\
\hline $1-2$ & 21 & 40 & Hayır & 22 & 42 \\
\hline \multirow{2}{*}{\multicolumn{3}{|c|}{$\begin{array}{l}3-4 \\
\text { Mesleki Denevim (vll) }\end{array}$}} & \multicolumn{3}{|c|}{ Sezon Bittiğinde Ne İș Yapıyorsunuz? } \\
\hline & & & Balıkçılık & 32 & 60 \\
\hline$\leq 5$ & 1 & 2 & Balık satışı & 14 & 27 \\
\hline $6-10$ & - & - & Tekne bakımı & 6 & 11 \\
\hline$\geq 11$ & 52 & 98 & Serbest meslek & 1 & 2 \\
\hline \multicolumn{3}{|c|}{ Eşiniz Çalışıyor mu? } & \multicolumn{3}{|c|}{ Balıkçılar Kooperatifine Üye Olma Durumu } \\
\hline Evet & 10 & 21 & Evet & 49 & 92 \\
\hline Hayır & 38 & 79 & Hayır & 4 & 8 \\
\hline
\end{tabular}




\section{Balıkçıların Ekonomik Durumu}

Balıkçıların bazı ekonomik özellikleri ile ilgili bilgiler Tablo 2'de verilmiştir. Balıkçıların \%64'ü mülkiyet sahibi olduğunu belirtmiş olup, bunların çoğunluğunun aileden kalma mülkiyet olduğu bildirmiştir. Balıkçılar genellikle (\%45) ürünlerini komisyoncu aracılığı ile satmaktadır.

Balıkçıların aylık masrafları 500-15.000 TL arasında değişmekte olup, \%45'inin aylık gideri 500$1.500 \mathrm{TL}$ civarındadır. Bu giderleri genellikle ağ, mazot ve bakım giderleri ile az bir kısmının da personel giderleri olduğu belirlenmiştir. Balıkçıların sezonluk ortalama kazançları 6.000 TL ile 60.000 TL arasında değişmekle birlikte, \%56'sının sezonluk kazancı 26.000 TL ve üzerindedir (Tablo 2).

Tablo 2. Balıkçıların Bazı Ekonomik Özellikleri

\begin{tabular}{|c|c|c|c|c|c|}
\hline & $\overline{\text { Sayı }}$ & $\%$ & & $\overline{\text { Sayı }}$ & $\overline{\%}$ \\
\hline \multicolumn{3}{|l|}{ Tekne Kendinize mi Ait? } & \multicolumn{3}{|c|}{ Aylık Gideriniz (TL) } \\
\hline Evet & 50 & 94 & $500-1.500$ & 24 & 45 \\
\hline Hayır & 3 & 6 & $1.600-2.500$ & 17 & 32 \\
\hline \multicolumn{3}{|l|}{ Mülkiyet Sahibi misiniz? } & $2.600-3.500$ & 6 & 11 \\
\hline Evet & 34 & 64 & 3.600 ve üzeri & 6 & 11 \\
\hline Hayır & 19 & 36 & \multicolumn{3}{|c|}{ Sezonluk Kazancinız (TL) } \\
\hline \multicolumn{3}{|c|}{ Balıkçılık ile İlgili Kredi Kullandınız mı? } & $6.000-10.000$ & 3 & 6 \\
\hline Evet & 23 & 43 & $11.000-15.000$ & 4 & 8 \\
\hline Hayır & 30 & 57 & $16.000-20.000$ & 13 & 25 \\
\hline \multicolumn{3}{|l|}{ Ürünü Pazarlama Şekli } & $21.000-25.000$ & 4 & 8 \\
\hline Komisyoncuya & 24 & 45 & $26.000-30.000$ & 13 & 25 \\
\hline Perakende Satış Yerlerine & 20 & 38 & $31.000-35.000$ & 4 & 8 \\
\hline Kendim satyyorum & 9 & 17 & 36.000 ve üzeri & 12 & 23 \\
\hline
\end{tabular}

\section{Kalkan Balığı Avcılığında Kullanılan Tekne ve Ağ Özellikleri}

Balıkçı teknelerinin tamamı ahşap olup, boylarının 9-11 m arasında değişmiş̧ir. Kalkan balığı avcılığında kullanılan ağlara ait bilgiler Şekil 2'de verilmiştir. Kalkan avcılığında kullanılan ağların; 2/3 dolu 1/3'ü boş 2 no mantarlar; 2-4 mm çapında PP mantar yakaya, tanesi 30-40 gr gelen kurşunlar; 2-4 mm çaplı, pp yaka ipi ve koşma ipine, ağın tam bir göz açıklığı $(34-36 \mathrm{~cm})$ bir çaka boyu alınıp, buna 3 ağ gözü alınarak donatıldığı belirlenmiştir (Şekil 2). Kalkan ağları donam faktörü (E) 0.33 olacak şekilde donatılır. Mantar yakada çaka boyu ağın bir tam gözü olacak şekilde, kurşun yakada ise, mantar yakaya göre $0.5 \mathrm{~cm}$ daha uzun olacak şekildedir. Kurşun yakada çaka boyunun daha uzun olması, ağın atılıp, çekilmesinde rahatlık sağladığı belirtilmiştir.

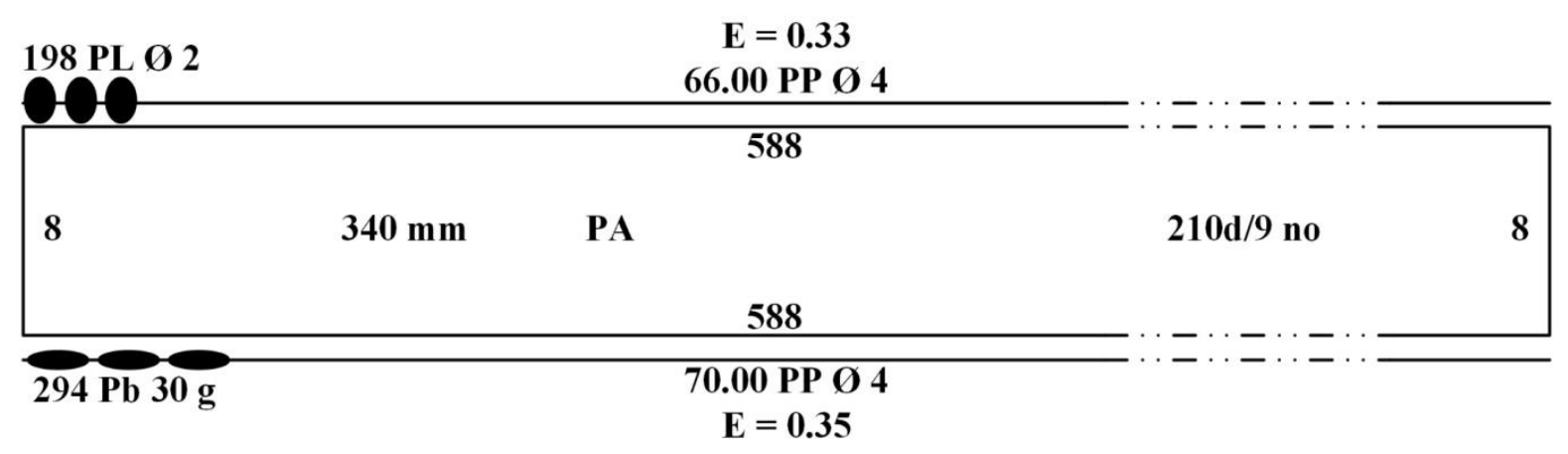

Şekil 2.Kalkan uzatma ağı

\section{Kalkan Balığının Boy Kompozisyonu}

Çalışmada incelenen 203 adet kalkan balığının, minimum, maksimum ve ortalama boy değerleri

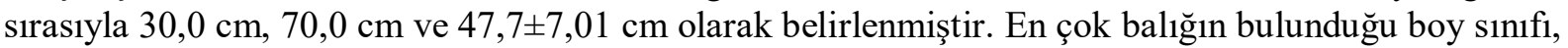
$\% 32,02$ ile 50-54 cm olarak belirlenmiştir (Tablo 3). 
Tablo 3. İncelenen Kalkan Balıklarının Boy Kompozisyonu

\begin{tabular}{ccc}
\hline \hline Boy Sinıfi (cm) & N & \% N \\
\hline $30-34$ & 10 & 4,93 \\
$35-39$ & 19 & 9,36 \\
$40-44$ & 26 & 12,81 \\
$45-49$ & 54 & 26,60 \\
$50-54$ & 65 & 32,02 \\
$55-59$ & 21 & 10,34 \\
$60-64$ & 6 & 2,96 \\
$65-69$ & 1 & 0,49 \\
$70-74$ & 1 & 0,49 \\
Toplam & 203 & 100 \\
\hline \hline
\end{tabular}

4/1 Numaralı Ticari Amaçlı Su Ürünleri Avcılığını Düzenleyen Tebliğ’e göre kalkan balıkları için yasal avlanma boy sınırı $45 \mathrm{~cm}$ 'dir. Buna göre incelenen kalkan balıklarının \%27'si 45 cm'nin altında \%73'ü ise $45 \mathrm{~cm}$ 'nin üstünde olduğu tespit edilmiştir (Şekil 3).

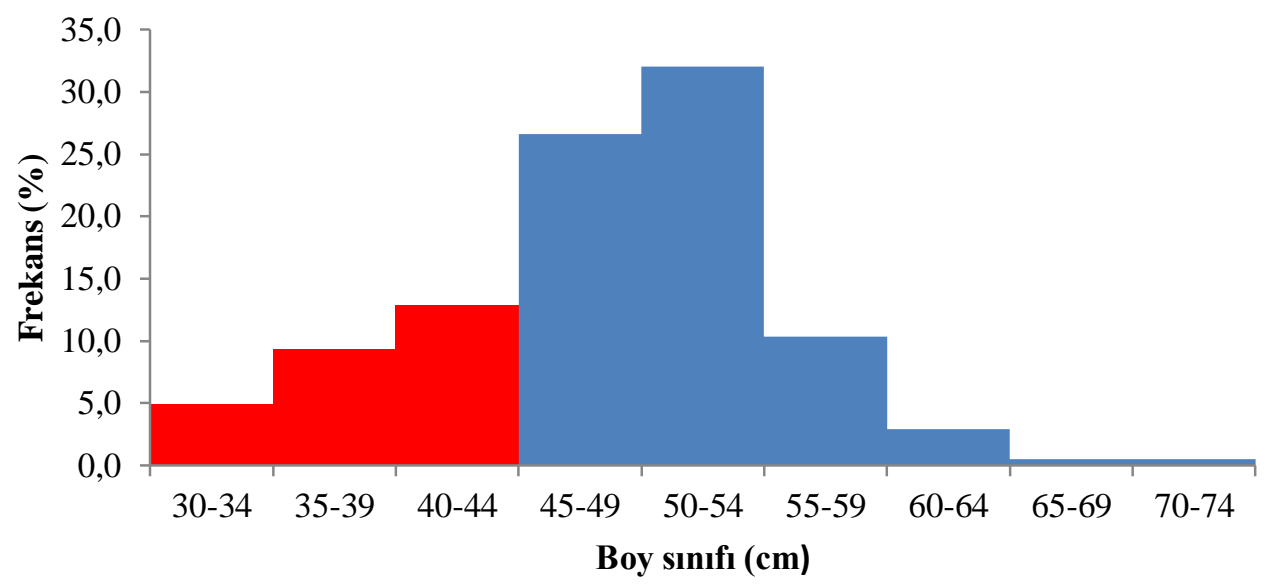

Şekil 3. Çalışmada İncelenen Kalkan Balıklarının Boy-Frekans Dağılımı

\section{TARTIŞMA ve SONUÇ}

Çalışmada balıkçıların \%25 ile çoğunluğunun 40-49 yaş aralığında olduğu anlaşılmaktadır. Yücel (2006), Orta Karadeniz Bölgesi'ndeki balıkçıların \%51'lik kesimin 30-50 yaş aralığında olduğunu, Özbek (2014) ise Giresun'da yürüttüğü çalışmada, tüm balıkçıların 40 yaş üstünde olduğunu bildirmişlerdir. Dartay ve Canpolat (2017), Keban Baraj Gölü balıkçılarının yaşlarının 20-69 arasında değiştiğini, çoğunluğun \%36,5 ile 40-49 yaş grubuna ait olduğunu belirtmiştir. Bayhan vd. (2014), Adıyaman ilindeki balıkçıların yaşlarının 18-59 arasında farklılık gösterdiğini ve \%50'lik oranla fazlalığın 36-50 yaşları arasında olduğunu belirtmiştir. Yapılan çalışmalardaki balıkçıların yaş ortalaması değerlendirildiğinde, gençlerin balıkçılığa ilgi duymadıkları ortaya çıkmaktadır.

Araştırmada, Giresun ilindeki balıkçıların öğrenim durumlarına bakıldığında \%57'sinin ilkokul, \%13'ünün ortaokul, \%24'ünün lise, \%2'sinin meslek yüksekokulu ve \%4'ünün fakülte mezunu olduğu tespit edilmiştir. Yücel (2006), Orta Karadeniz Bölgesi'ndeki çalışmasında balıkçıların \%1'inin eğitiminin yüksekokul seviyesinde olduğunu, Uncumusaoğlu (2015), Giresun İli’ndeki balıkçıların \%3'ünün okur-yazar, \%55'inin ilkokul, \%19'unun lise, \%17'sinin ortaokul ve \%6'sinın da üniversite mezunu olduğunu, Sağlam vd., (2016) Giresun'da balıkçıların \%60'ının ilkokul, \%20'sinin ortaokul, $\% 15$ 'inin lise ve \%5'inin üniversite mezunu olduğunu belirtmişlerdir. Yapılan tüm çalışmalarda sonuçlar benzerlik göstermekte olup, balıkçıların çoğunluğunun ilkokul mezunu olduğu dikkat çekmektedir. Bunun nedeni olarak eğitimine devam eden kişilerin meslek tercihlerinin başka alanlarda olması düşünülmektedir. 
Çalışmada, balıkçılarının \%39'unun sosyal güvencesinin olduğu ve \%23'ünün emekli olduğu gözlenmiştir. Özbek (2014), balıkçıların tamamının sosyal güvenceye sahip olduğunu, Yücel (2006), \%56'sının herhangi bir sosyal güvencesinin olmadığını, Yiğit vd. (2010), \%20'sinin sosyal güvencesi olmadığını, \%80'inin ise sigortalı olduğunu belirtmişlerdir. Balıkçılar, dışarıdan kendi imkanları ile sosyal güvence yapmayı tercih etmediklerini, ayrıca emeklilikten sonrada genellikle balıkçılık mesleğine devam ettiklerini ifade etmişlerdir.

Sunulan çalışmada, balıkçıların \%92'sinin kooperatife üye olduğunu belirtmekle birlikte \%75'inin kooperatiften bir beklentilerinin olmadığını ifade etmiştir. Sağlam vd. (2016), Doğu Karadeniz Bölgesi'ndeki balıkçıların \%54'ünün kooperatife üye olduğunu belirtmiştir. Balıkçıların üye olma sebeplerinin başında saygınlık görmek ve kooperatifin imkanlarından yararlanmak gelmesi dikkat çekicidir. Kooperatif üyelerinin birlik ve beraberlik içinde hareket ettiği, birbirlerine ve mesleklerine sahip çıkmaya çalıştıkları anlaşılmaktadır. Kooperatiften beklentisi olan kişiler ise özellikle liman düzenlemesi ve çekek yeri konusunda çalışma sağlanmasını istemişlerdir.

$\mathrm{Bu}$ çalışmada, balıkçıların mesleki deneyimi 4-60 yıl arasında değişmekle birlikte \%98 oranı ile çoğunluğunun 11 y1l ve üzeri deneyime sahip olduğu tespit edilmiştir. Sağlam vd., (2016), \%21'inin 40 yıldan fazla süredir, \%37'sinin ise ortalama 25 yıldır balıkçılık yaptığı, minimum 1 yıllık maksimum 75 yıllık balıkçılık deneyimi olan balıkçıya rastlandığını tespit etmiştir. Balıkçılık mesleğine küçük yaşlardan itibaren başlamaları ve emekli dahi olsalar mesleğe devam etmeleri dikkat çekicidir. Diğer yandan özellikle baba mesleği olduğu için çocuk yaşlarda balıkçılık mesleğine başladıklarını ve zor şartlara rağmen, ekonomik ve coğrafik koşullar nedeniyle mesleğin devamlılığını gösterdiklerini ifade etmişlerdir. Balıkçıların meslek seçimini incelediğimizde kişilerin genellikle ilkokuldan sonra balıkçılık mesleğine başladıkları ve baba mesleği olduğu için başka bir iş aramadıkları belirlenmiştir. Diğer yandan \%51'lik bir kısmın yaptıkları işten memnun oldukları, bu mesleği ata mesleği olduğu için seçtikleri ve küçük yaşlardan itibaren balıkçılık işiyle uğraştıkları ve başka meslek düşünmedikleri görülmüştür.

Balıkçıların ekonomik durumları incelendiğinde, sezonluk kazançları 6.000-60.000 TL arasında olup, ortalama 28.981 TL'dir. Buna karşllık giderleri, 500-15.000 TL arasında değişim göstermektedir. Balıkçılar, giderlerin çoğunluğunu ağ, mazot giderlerinin oluşturduğunu ve bunların devamlı bir gider olduğu için en uygun maliyet çıkacak şekilde temin etmeye çalıştıklarını belirtmişlerdir. Balıkçıların zor şartlara rağmen gerek ekonomik ihtiyaçlardan gerekse mesleği devam ettirebilmek için balıkçlığı bırakmak istemedikleri düşünülmektedir.

Balıkçıların \%94'ünün kendisine veya ailesine ait teknesi olduğu, \%21'inin eşlerinin çalıştığı, \%79'unun çalışmadığı ve balıkçıların teknelerini bakıma aldıklarında eşlerinin yardımcı olduğu ve ağ dokuma işlerini yaptıkları belirtilmiştir. Bu veriler Karadeniz balıkçılığında kadının azımsanmayacak bir yeri olduğunu göstermektedir.

Balıkçıların \%57'si geri ödemede zorluk yaşayacağını düşündügünden balıkçılıkla ilgili kredi kullanmadıklarını ve \%64'ü mülkiyet sahibi olduklarını belirtmişlerdir. Özbek (2014), Giresun balıkçılarının \%78'inin mülkiyet sahibi olduğunu bildirmiştir. Sağlam vd., (2016), Doğu Karadeniz Bölgesi'ndeki balıkçıların \%68'inin ev sahibi, \%31'inin kiracı olduğunu bildirmişlerdir. Karadal (2014), Akdeniz bölgesindeki balıkçıların \%61'inin ev sahibi, \%39'unun kiracı olduğunu tespit etmiştir. Balıkçıların çoğunluğunun mülkiyet sahibi olması dikkat çekmekle birlikte bunun aileden kalma mülkiyet olduğu yapılan görüşmelerde ifade edilmiştir.

Pazarlama işi çoğunlukla komisyoncular vasıtasıyla yapılmaktadır. Araştırmada katılımcı balıkçılarının \%64'ü kalkan avcılığı yapmaktadır. Özellikle son dönemlerde kalkan balığı popülasyonundaki azalış sebebiyle avcılık için harcanan masrafı karşılamaması, Giresun'un bazı kesimlerinde denizin aşırı kirli olması ve denize atılan ağın kirlilik ve yunus saldırılarından zarar görmesi gibi nedenlerden dolayı, balıkçıların, zamanla kalkan avcılığını bıraktıkları belirlenmiştir. Balıkçılar, kalkan avcılı̆̆ 1 yerine diğer balık türleri avcılığına yönelmektedir.

Çalışmada kullanılan kalkan ağlarının donam faktörü 0,33 tür. Samsun ve Kalaycı (2004)'nın, Orta Karadeniz ve İstanbul bölgesindeki çalışmalarında kullanılan kalkan ağlarının donanımları benzer olup ağların donam faktörü 0,33 tür. Yıldız ve Karakulak (2010), İstanbul bölgesi için kullanılan kalkan ağlarının donam faktörünü 0,27 şeklinde bildirmiştir. Bölgeler arasında donam faktörü bakımından önemli bir farklılık olmadığı saptanmıştır.

Araştırmada incelenen kalkan balıklarının boyları minimum $30 \mathrm{~cm}$, maksimum $70 \mathrm{~cm}$ ve ortalama

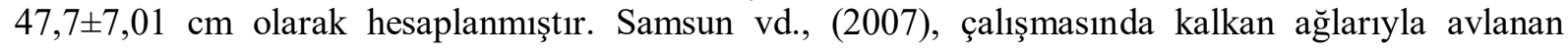


balıkların boy dağılımını, erkek ve dişi bireyler için 23,9-69 $\mathrm{cm}$ ve 31,8-81 $\mathrm{cm}$ arasında tespit etmiştir. Ortalama toplam boylar ise, dişiler için $50,37 \pm 0,4 \mathrm{~cm}$, erkekler için $45,93 \pm 0,26 \mathrm{~cm}$ ve tüm bireyler için 47,79 $\pm 0,24 \mathrm{~cm}$, olarak belirtilmiştir. Özdemir vd.,(2017), Eylül 2015-Haziran 2016 tarihleri aras1 Sinop içliman bölgesi açıklarında kalkan ağlarıyla avlanan kalkan balıklarının boylarını minimum 33,4 $\mathrm{cm}$, maksimum $70 \mathrm{~cm}$, ortalama boy $51,9 \pm 1,40 \mathrm{~cm}$ olarak hesaplamıştır. Her iki çalışmadaki genel boy kompozisyonu bu çalışma ile benzerlik göstermektedir.

Yapısı itibariyle dünya denizlerinden farklı özelliğe sahip olan Karadeniz'de bulunan balık stoklarının bilinmesi ve bu durum dikkate alınarak yönetim tedbirlerinin belirlenmesi diğer balıklarda olduğu gibi kalkan stoklarının da korunmasında oldukça önemlidir. Balıkçılık ve Su Ürünleri Genel Müdürlüğü’nün stok tahmini yapılamamasına rağmen kalkan avcıllğını sürekli izlemeye yönelik ağ uzunluğu, derinliği, boy kompozisyonu, deniz memelileri dahil avlanan hedef dışı türler ve birim ağ uzunluğunda av veriminin tespitine yönelik operasyonel veri toplama programlarını başlatması, titizlikle izlemesi ve analiz etmesi, kalkan avcılığına ilişkin yönetim önlemleri alınmasını sağlayabilir.

Yapılan bu araştırmada, Giresun ilinde, balıkçılığın bölge insanının yaşamında sosyal ve ekonomik anlamda önemli bir yeri olduğu görülmüştür. Yıllara göre üretim miktarında azalmalar olsa da yöre insanının balık avcılığına sosyal, ekonomik ve hatta kültürel boyutlarda bağlı kalması dikkat çekmektedir.

Karadeniz'in orta kısmının bir bölümünün ve doğu kısmının tamamının trol avcıllı̆̆ına kapalı oluşundan dolayı küçük ölçekli balıkçılık bu bölgelerde birbirlerine benzerlik göstermektedir. Bu sebeple Giresun ili küçük ölçekli balıkçılığı orta ve doğu Karadeniz için bir alt örneklem kabul edilebilir. Giresun ilinde bulunan kalkan balıkçılarının, sosyo-demografik yapıları ve avladıkları kalkan balığı durumunun incelenmesi Karadeniz küçük ölçekli balıkçılığı açısından oldukça önemlidir. Balıkçıların ekonomik olarak zorluk yaşadıkları ve balıkçılık tecrübelerinin yüksek olmasına rağmen yasal boyun altındaki balıkları ekonomik kaygılar nedeniyle satışa sundukları görülmektedir. Bu sorunun giderilmesi için hem balıkçıların kazançlarının yükseltilebilmesi hem de kalkan balığının stokunun korunması için gerekli yasal çalışmaların yapılabilmesi açısından bu çalışma önem arz etmektedir. Bu çalışma, bu tarz çalışmaların bu bölgede arttırılarak, yapılması planlanacak olan yasal düzenlemeler için önemli bir kaynaktır.

Teşekkür: Bu çalışma “Giresun İli'nde Kalkan (Scophthalmus maximus Linnaeus, 1758) Balıkçıllı̆ı ve Kalkan Balıkçılarının Sosyo-Demografik Yapısı” başlıklı, Aslıhan Demircan Aktar'ın yüksek lisans tezinden özetlenmiştir. (Ordu Üniversitesi Fen Bilimleri Enstitüsü - 2019).

\section{KAYNAKLAR}

Acara, A. (1985). The Black Seaturbot. State Planning Organization, Ankara-Turkey, 19pp.

Anonim a. (2018). Gıda Tarım ve Hayvancılık Bakanlığı Su Ürünleri İstatistikleri. (Erişim tarihi: 04.05.2019).

Anonim b. (2018).4/1 Numaralı Ticari Amaçlı Su Ürünleri Avcıllı̆ını Düzenleyen Tebliğ 2016-2020, (Tebliğ No: 2016/35)

Bayhan, Y. K., Korkmaz, S., \& Olgunoğlu, M. P. (2014). Adıyaman İli balıkçılığının mevcut durumu ve sorunları. Yunus Araştırma Bülteni, 4, 37-46.

Dartay, M., \& Canpolat, İ. (2017). Keban Baraj Gölü (Elazığ, Türkiye) Su ürünleri kooperatiflerine ortak balıķ̧ıların sosyo- ekonomik yapısı. Ege Üniversitesi Su Ürünleri Dergisi, 34(1), 41-46.

Erdoğan Sağlam, N., \& Çalık, S. (2016). Giresun İli balıkçılığına genel bir bakış. Ordu Üniversitesi Bilim Teknoloji Dergisi, 6(2), 28-37.

Erdoğan Sağlam, N., Özbek, G., \& Düzgüneş, E. (2016). Doğu Karadeniz Bölgesi’nde deniz balıkçılarının sosyo-ekonomik yapısı. Gaziosmanpaşa Üniversitesi Ziraat Fakültesi Dergisi, 33(3), 259-270.

Ergüven, N.S. (2014). Karadeniz'de deniz alanı sinırlandırması davası (Romanya/Ukrayna) ve uluslararası hukuk açısından etkileri. Ankara Üniversitesi Hukuk Fakültesi Dergisi, 63(2), 309-328.

Karadal, E. (2014). Akdeniz Bölgesi (Türkiye) sahil şeridi deniz balıkçılı̆̆ının sosyo-ekonomik durumu. Ordu Üniversitesi, Fen Bilimleri Enstitüsü, Yüksek Lisans Tezi. Ordu.

Muus, B., \& Dahlström, P. (1978). Meeresfische der Ostsee, der Nordsee, des Atlantiks. BLV Verlagsgesellschaft, München, $244 \mathrm{pp}$.

Nelson, J. S. (1994). Fishes of the World. 3rd edn. Wiley, New York.

Özbek, Ö. (2014). Doğu Karadeniz Bölgesi (Türkiye) sahil şeridi deniz balıkçılı̆̆ının sosyo-ekonomik durumu. Ordu Üniversitesi, Fen Bilimleri Enstitüsü, Yüksek Lisans Tezi, Ordu.

Özdemir S., Erdem Y., Özsandıkçı U., \& Büyükdeveci F. (2017). Kalkan avcılığında kullanılan uzatma ağlarının Orta Karadeniz kıyllarındaki mevsimsel av kompozisyonu. Yunus Araştırma Bülteni, 4, 325-334 
Samsun, N., \& F. Kalayc1. (2004). The determination of turbot tangle net sand trammel nets features, catch per unit effort (CPUE) and turbot fishing in Middle Black Sea (Sinop). Süleyman Demirel Üniversitesi Ĕgirdir Su Ürünleri Fakültesi Dergisi, 2(12), 99-108.

Samsun, N., Kalayc1, F., \& Samsun, O. (2007). Seasonal variation in length, weight and sex distribution of turbot (Scophthalmus maeoticus Pallas, 1811) in the Sinop region (Black Sea) of Turkey. Turkish Journal of Zoology. 31, 371-378.

Suzuki, N., Nishida, M., Yoseda, K., Ustundag, C., Sahin, T., \& Amaoka, K. (2004). Phylogeographic relationships with in the Mediterranean turbot inferred by mitochondrial DNA haplotype variation. Journal of Fish Biology, 65(2), 580- 585.

Turan, C. (Ed.) (2007). Atlas and Systematics of Marine Bony Fishes of Turkey. 1st edition, Nobel Publishing House, Adana, Turkey.

Turan, C., Ivanova P., Gürlek M., Yağlioğlu D., Ergüden D., Karan S., Doğdu S. A., Uyan A., Öztürk B., Nikolov V., Raykov V., Dobrovolov I., \& Khanaychenko A. (2019). Phylogenetic relationships of turbot species (Scophthalmidae) inferred from the mitochondrial COIII Gene and morphological characters. Natural and Engineering Sciences, 4(1), 28-41. https://doi.org/10.28978/nesciences.522593.

Uncumusaoğlu, C. (2015). Giresun'da deniz balıkçılı̆̆ı ve balıkçıların sosyo-ekonomik yapısı. Giresun Üniversitesi, Fen Bilimleri Enstitüsü, Yüksek Lisans Tezi, Giresun.

Yıldız, T.,\&Karakulak F. S. (2010). İstanbul kıyı balıkçılığında kullanılan dip uzatma ağlarının teknik özellikleri. Ege Üniversitesi Su Ürünleri Dergisi, 27(1), 19-24.

Yiğit, H., Soylu, M., \& Uzmanoğlu, S. (2010). Sakarya İli göllerinin balıkçı profili. İstanbul Üniversitesi Su Ürünleri Dergisi, 24(2), 9-23.

Yücel, Ş. (2006). Orta Karadeniz Bölgesi balıkçılığı ve balıkçıların sosyo-ekonomik durumu. Ege Üniversitesi Su Ürünleri Dergisi, 23, 530-532. 